\title{
EFISIENSI PEMASARAN GAMBIR DI KABUPATEN LIMA PULUH KOTA, SUMATERA BARAT
}

\author{
Marketing Efficiency of Gambier in Lima Puluh Kota Regency, \\ West Sumatera
}

\author{
Amelira Haris Nasution 1, Ratna Winandi Asmarantaka ${ }^{2)}$ dan Lukman M Baga ${ }^{2)}$ \\ 1,2Jalan Kamper, Wing 4 Level 5 Kampus IPB Dramaga, Bogor, Indonesia 16680 \\ email : liranasution@gmail.com
}

Naskah diterima: 08/05/2015 Naskah direvisi: 22/06/2015 Disetujui diterbitkan: 06/08/2015

\begin{abstract}
Abstrak
Penelitian ini bertujuan untuk menganalisis efisiensi pemasaran gambir di Kabupaten Lima Puluh Kota, Sumatera Barat dengan menggunakan analisis efisiensi operasional dan efisiensi harga. Penentuan responden petani dipilih dengan menggunakan metode purposive sampling, dan responden pedagang dipilih dengan snowball sampling. Data primer digunakan untuk melakukan analisis efisiensi operasional, sedangkan data sekunder time series bulanan dalam periode 2004 - 2014 digunakan untuk analisis efisiensi harga. Berdasarkan analisis efisiensi operasional terbukti bahwa saluran pemasaran yang terbentuk belum efisien akibat posisi tawar petani yang rendah. Dengan analisis efisiensi harga terungkap bahwa dalam jangka pendek, pasar gambir di tingkat petani tidak terintegrasi dengan pedagang besar dan ekportir, dan dalam jangka panjang pasar gambir di tingkat pedagang besar berkorelasi dengan eksportir namun tidak terintegrasi. Korelasi ini mengindikasikan adanya kolusi antara pedagang besar dan eksportir. Oleh karena itu, peran pemerintah diperlukan, terutama untuk mengoptimalkan regulasi pasar gambir yang ada dan meningkatkan peran kelembagaan petani. Kebijakan perbaikan akses informasi pasar dan ekspor gambir akan mampu menciptakan pemasaran gambir yang berpihak pada petani gambir.
\end{abstract}

Kata kunci : Gambir, Efisiensi Operasional, Efisiensi Harga.

\begin{abstract}
This study aims at analyzing the market efficiency of gambier in Lima Puluh Kota Regency, West Sumatera using analysis of operational and price efficiency. Farmers were chosen using purposive sampling method and middlemen were selected using snowball sampling method. Primary data were used for the operational efficiency analysis, and secondary data which was monthly time series data from 2004 to 2014 were utilized for the price efficiency analysis. Based on the operational efficiency analysis, it was proven that the marketing channels had been inefficient because the bargaining power of farmers was weak. By using the price efficiency analysis, it showed that in the short run, gambier market in the farm level was not integrated with the middlemen and exporter levels, whereas in the long run, gambier market in middlemen level had corellation with the exporter level but they had not been integrated. This corellation indicated that there was a collusion between the middlemen and the exporters. Therefore, the role of government is needed to maximize the regulation of gambier market and to increase the role of farmer institutions. This can be done by improving the market access information and gambier export policy to create marketing which supports the gambier farmers.
\end{abstract}

Keyword: Gambier, Operational Efficiency, Price Efficiency

JEL Classification: D43, L13, Q02, Q13 


\section{PENDAHULUAN}

Gambir adalah salah satu komoditas perkebunan rakyat dan menjadi komoditas ekspor Indonesia yang diperoleh dari pengempaan daun dan ranting tanaman Uncaria gambier (hunt) roxb. Ekstrak gambir memiliki kandungan senyawa polifenol berupa katekin dan tanin. Kedua kandungan inilah yang kemudian memberikan nilai ekonomi karena dimanfaatkan sebagai bahan baku industri farmasi seperti pasta gigi, kosmetik, penyamakan kulit, pewarna, dan bahan industri makanan.

Indonesia menempati posisi yang sangat penting sebagai produsen gambir terbesar, dengan memasok $80 \%$ kebutuhan gambir dunia (Adi, 2011). Keunggulan komparatif yang dimiliki Indonesia berupa kecocokan iklim dan topografi yang sesuai dengan budidaya gambir memberikan efek positif terhadap produksi dan ekspor gambir setiap tahunnya, sehingga Indonesia menjadi pemasok utama gambir dunia.

Berdasarkan data Trade Map tahun 2014 dengan HS 320190100 Gambier dan 3201901000 Gambier, tren perkembangan ekspor gambir Indonesia pada tahun 2011 hingga 2012 cenderung meningkat dengan laju pertumbuhan sebesar $2.35 \%$. Indonesia memiliki 17 negara tujuan ekspor yaitu India, Pakistan, Bangladesh, Singapura, Jepang, Malaysia, Vietnam, Korea Selatan, Nepal, Turki, Srilanka, China, Saudi Arabia, Taipei, Uni Emirat Arab, Thailand, dan Amerika Serikat. Diantara 17 negara tersebut, terdapat 4 negara tujuan utama ekspor gambir Indonesia dengan kuantitas lebih dari 100 ton setiap tahunnya yaitu India, Pakistan, Bangladesh dan Singapura (Trade Map, 2014).

Produksi gambir nasional dihasilkan dari empat provinsi sentra penghasil gambir, yaitu Sumatera Barat, Sumatera Utara, Riau, dan Sumatera Selatan. Diantara keempat provinsi tersebut Sumatera Barat merupakan sentra gambir terbesar dan mampu memasok $80 \%$ hingga $90 \%$ dari total produksi gambir nasional. Bahkan menurut data BPS (2013) dalam rentang 2010 hingga 2013 kuantitas ekspor dan nilai ekspor gambir Sumatera Barat cenderung meningkat. Oleh karena itu, Sumatera Barat diposisikan sebagai barometer gambir nasional (Sa'id, 2010).

Di Provinsi Sumatera Barat terdapat 2 daerah terpenting penghasil gambir yaitu Kabupaten Lima Puluh Kota dan Kabupaten Pesisir Selatan. Kabupaten Lima Puluh Kota merupakan penghasil gambir terbesar daerah ini, yang tahun 2013 mampu memasok 69.75\% dari total produksi gambir Sumatera Barat (BPS, 2014).

Memiliki posisi sebagai negara penghasil terbesar gambir dunia, Indonesia diharapkan mampu meningkatkan kesejahteraan petani gambir. Posisi Indonesia yang bisa menjadi pemegang kendali dengan keunggulan komparatif sebagai penghasil gambir terbesar di dunia memungkinkan untuk itu. Oleh karena itu, secara normatif Indonesia seharusnya bisa menjadi pelaku monopoli dalam pemasaran gambir. Akan tetapi, harapan tersebut ternyata belum menjadi kenyataan. Adanya 
paradoks posisi gambir Indonesia yang mendunia, justru belum dinikmati petani gambir Indonesia sebagai produsen utama gambir. Hal itu terjadi antar lain akibat sistem budidaya yang masih konvensional, lemahnya agroindustri pengolahan gambir, buruknya peran kelembagaan tingkat petani, dan tidak efisiennya pemasaran gambir (Afrizal, 2009; Adi, 2011; Elida, 2011). Bahkan menurut Idrus (2012), sektor agroindustri gambir tidak mengalami perkembangan yang berarti, walaupun tren luas lahan dan produksi gambir sebagai komoditas unggulan akan terus meningkat hingga tahun 2016.

Disisi lain, mekanisme pembentukan harga gambir hingga saat ini masih berdasarkan harga yang ditentukan oleh eksportir dan importir gambir. Afrizal (2009) menyebutkan eksportir merupakan lembaga pemasaran yang bertindak sebagai penentu harga gambir, dengan kecenderungan informasi harga di tingkat eksportir/ importir yang tertutup sehingga perubahan harga gambir menimbulkan ketidakpastian bagi petani. Meskipun harga gambir menurut BAPPENAS dan GIZ (2013) mengindikasikan meningkat dari waktu ke waktu, yang rata-rata selama periode 2001-2010 sebesar $4,94 \%$ pertahun, namun peningkatan tersebut cenderung tidak dirasakan petani. Hal ini memperkuat dugaan bahwa sistem pemasaran gambir tidak efisien, akibat harga ditingkat eksportir tidak terintegrasi dengan harga ditingkat petani. Selain itu, tidak diketahuinya harga riil di pasar internasional juga menjadi salah satu permasalahan dalam kegiatan pengembangan gambir (Evalia et al. 2012). Terlebih lagi informasi harga internasional cenderung tidak dapat diperoleh pada lembaga pemerintahan terkait seperti halnya komoditas unggulan nasional (cacao dan kelapa sawit) karena posisi gambir yang bukan merupakan komoditas unggulan nasional. Tertutupnya informasi harga gambir tersebut menyebabkan lemahnya bargaining power petani gambir dan menempatkan petani gambir sebagai price taker dalam sistem pemasaran gambir.

Penelitian ini bertujuan untuk menganalisis efisiensi pemasaran gambir dengan menggunakan analisis efisiensi operasional dan analisis efisiensi harga sebagaimana yang dianjurkan oleh Kohl \& Uhl (2002) dan Asmarantaka (2012). Analisis efisiensi operasional dilakukan dengan menggunakan analisis margin pemasaran dan farmershare, sedangkan analisia efisiensi harga dilakukan dengan menggunakan analisis integrasi pasar gambir. Diharapkan dengan adanya informasi ini akan berkontribusi terhadap alternatif kebijakan dalam pengembangan gambir, khususnya dalam pemasaran gambir.

\section{METODE}

Penelitian dilakukan di Kecamatan Mungka dan Kecamatan Harau, Kabupaten Lima Puluh Kota, Sumatera Barat. Pengumpulan data dilaksanakan pada bulan Desember 2014 hingga Januari 2015.

Penelitian ini menggunakan data primer dan data sekunder. Data primer 
dikumpulkan dengan menggunakan metode survei melalui wawancara langsung dengan petani sebayak 32 orang dan pedagang gambir sebanyak 13 orang. Pengumpulan data primer ini menggunakan daftar pertanyaan berupa kuisioner. Pengumpulan data sekunder diperoleh melalui penelusuran data dengan alat bantu internet, mengunjungi perpustakaan serta lembaga-lembaga terkait. Data primer digunakan pada analisis efisiensi operasional dan penggabungan data primer serta data sekunder digunakan pada analisis efisiensi harga dalam bentuk time series (data bulanan tahun 2004 hingga 2014).

Pengolahan data menggunakan analisis deskriptif kualitatif dan kuantitatif. Analisis kualitatif digunakan untuk medeskripsikan saluran pemasaran gambir dan analisis kuantitatif digunakan untuk mengukur efisiensi operasional melalui margin pemasaran dan farmer share, serta efisiensi harga melalui analisis integrasi pasar. Pengolahan untuk perhitungan efisiensi operasional dilakukan dengan menggunakan Microsoft Excel 2007, sedangkan pengolahan untuk perhitungan efisiensi harga menggunakan software Eviews 7.

\section{Efisiensi Operasional}

Efisiensi operasional berhubungan dengan pelaksanaan aktivitas pemasaran yang dapat meningkatkan atau memaksimumkan rasio outputinput pemasaran (Asmarantaka, 2012). Analisis yang digunakan adalah analisis margin pemasaran dan farmer's share.

\section{Analisis Margin Pemasaran}

Margin pemasaran digunakan untuk menganalisis sistem pemasaran dalam perspektif makro, yaitu menganalisis pemasaran produk mulai dari petani produsen sampai ke tangan konsumen akhir. Dari perseptif mikro atau perusahaan tertentu, margin pemasaran merupakan selisih harga jual dengan harga beli atau margin pemasaran merupakan biaya-biaya dan keuntungan dari perusahaan tersebut akibat adanya aktivitas bisnis yang dilakukan perusahaan (Asmarantaka, 2012). Secara matematis, model yang digunakan untuk mengukur margin pemasaran adalah:

$$
\begin{aligned}
& M T=\operatorname{Pr}-P f=\text { Biaya }^{2}+\pi \text { Lembaga }=\sum M i \\
& M i=P_{j i}-P_{b i} \ldots \ldots \ldots \ldots \ldots \ldots \ldots \ldots \ldots \ldots \ldots \ldots \ldots \ldots \ldots \ldots \ldots \ldots \ldots \ldots \ldots
\end{aligned}
$$

Dimana:

$$
\begin{array}{ll}
\text { MT } & \text { : Margin Total } \\
\mathrm{Mi} & : \text { Marjin di tingkat lembaga } \\
& \text { ke i, dimana } \mathrm{i}=1,2, \ldots, \mathrm{n} \\
\mathrm{Pr} & : \text { Harga ditingkatkonsumen } \\
& \text { akhir } \\
\mathrm{Pf} & : \text { Harga di tingkat produsen } \\
\mathrm{T} \text { lembaga } & : \text { Profit lembaga pemasaran } \\
& \text { akibat adanya sistem } \\
& \text { pemasaran } \\
\mathrm{Pji} & : \text { Harga penjualan untuk } \\
& \text { lembaga pemasaran ke-i } \\
\mathrm{Pbi} & \text { Harga pembelian untuk } \\
& \text { lembaga pemasaran ke-i }
\end{array}
$$

Dalam menginterpretasi margin pemasaran perlu kehati-hatian. Margin pemasaran yang meningkat, tetapi banyak perlakuan (fungsi-fungsi) yang terjadi dan konsumen puas terhadap produk akhir, menunjukkan 
kecenderungan sistem pemasaran produk tersebut efisien.

\section{Analisis Farmer's Share}

Farmer's share merupakan porsi dari harga yang dibayarkan konsumen akhir terhadap petani dalam bentuk persentase. Besarnya farmer share dipengaruhi oleh tingkat pemrosesan, biaya transportasi, keawetan produk, biaya transportasi, dan jumlah produk (Kohls \& Uhl, 2002). Semakin tinggi farmer share menyebabkan semakin tinggi pula bagian harga yang diterima petani. Rumus yang digunakan dalam menghitung farmer's share adalah:

$F^{\prime} S=\left\{\frac{P f}{P r}\right\} X 100 \%$

Dimana:

F's : Farmer's Share

Pf : Harga ditingkat produsen

$\operatorname{Pr}$ : Harga ditingkat retail (tingkat konsumen akhir)

\section{Efisiensi Harga}

Efisiensi harga menekankan kepada kemampuan sistem pemasaran dalam mengalokasikan sumberdaya dan mengkoordinasi seluruh produksi pertanian dan proses pemasaran sehingga efisien yang sesuai dengan keinginan konsumen (Asmarantaka, 2012). Analisis efisiensi harga dapat menggunakan indikator tingkat keterpaduan pasar atau analisis integrasi harga.

Integrasi atau keterpaduan pasar merupakan suatu indikator efisiensi harga yang menunjukkan bagaimana hubungan harga antar wilayah atau antar lembaga yang terjadi dalam sistem pemasaran komoditas tertentu. Integrasi pasar melihat sejauhmana harga di pasar lokal dipengaruhi oleh harga di pasar acuan dengan mempertimbangkan harga pada waktu yang lalu dan harga pada saat ini. Perubahan harga ini dapat disebabkan oleh adanya perubahan margin pada pasar lokal dan acuan pada waktu sebelumnya (lag-times). Integrasi pasar dapat dibedakan menjadi 2 jenis, yaitu integrasi pasar vertikal dan integrasi pasar horizontal. Integrasi pasar vertikal merupakan integrasi yang dipahami terjadi dalam suatu industri (sistem agribisnis), yakni keterkaitan lembaga pemasaran dengan lembaga pemasaran lainnya dalam satu rantai pemasaran (misalnya dari lembaga ditingkat petani dengan lembaga di pabrik atau tingkat konsumen). Sedangkan integrasi horizontal meliputi integrasi pasar spasial, temporal, dan integrasi harga silang.

Asmarantaka (2012) menyebutkan tingkat integrasi suatu pasar dapat dinilai dengan menggunakan beberapa metode, diantaranya yaitu: (1) analisis korelasi harga, (2) analisis regresi sederhana, (3) model pasar deret waktu yang dikembangkan oleh Ravallion. $M$ (1986) dan Haytens PJ (1986) dalam Asmarantaka (2012), pada model ini menjelaskan bahwa harga pada periode berjalan (current) dapat berubah secara distributed lag berdasarkan periode lalu atau pasar lain, (4) model deret waktu yang diuji stasioner dengan menggunakan Augmanted Dickey Fuller (ADF) test kemudian menggunakan VAR (Vector Autoregression). 
Dalam penelitian ini, analisis yang dilakukan adalah analisis integrasi pasar vertikal. Analisis integrasi pasar yang digunakan adalah analisis model yang dikembangkan oleh Ravallion (1986) dalam Asmarantaka (2012). Model ini dipilih karena model tersebut mampu mengungkapkan secara mendetail peran pasar acuan, arah transmisi harga, kecepatan transmisi harga, tingkat keterisolasian, dan tingkat keterpaduan pasar.

Harga pasar lokal diartikan sebagai harga gambir pada tingkat petani (Pi), sedangkan harga di pasar acuan adalah harga gambir yang berlaku di tingkat eksportir $(\mathrm{Pt})$, sehingga model dapat ditulis sebagai berikut:

Pit $=(1+b 1)$ Pit- 1+b2(Pt $-P t-1)+(b 3-b 1)$ $\mathrm{Pt}-1+\mathrm{b} 4 \mathrm{X}$

Dimana:

Pit : Harga gambir di tingkat petani (waktu t) $(\mathrm{Rp} / \mathrm{kg})$

Pit-1 : Harga gambir di tingkat petani (waktu t-1) (Rp/kg)

Pt : Harga gambir di tingkat eksportir (waktu t) (Rp/kg)

Pt-1 : Harga gambir di tingkat eksportir (waktu t-1) (Rp/kg)

$X$ : Faktor-faktor lain yang mempengaruhi

Koefisien $b_{2}$ menunjukkan seberapa jauh perubahan harga di tingkat eksportir di transmisikan ke tingkat petani. Koefisien (1+b1) dan (b3-b1) mencerminkan seberapa jauh kontribusi relatif harga periode sebelumnya dari tingkat petani dan ditingkat eksportir terhadap tingkat harga yang berlaku sekarang ditingkat petani. Rasio antara keduanya merupakan indeks hubungan pasar (Index Of Market Connection) atau IMC yang menunjukkan tinggi rendahnya keterpaduan antara kedua pasar yang bersangkutan dan dirumuskan sebagai berikut :

$\mathrm{IMC}=\frac{(1+\mathrm{b} 1)}{(b 3-b 1)}$

\section{Dimana :}

IMC : Indeks of marketing connection

Pasar dikatakan tidak ada hubungan/tidak terintegrasi pada jangka pendek jika IMC tinggi dan pada jangka panjang jika nilai sangat mendekati 0 . Jika terjadi integrasi maka perubahan harga yang terjadi di tingkat konsumen akan ditransmisikan ke tingkat produsen sehingga petani akan menerima perubahan atas harga yang terjadi pada tingkat konsumen.

Integrasi jangka pendek terjadi apabila b1 = -1 dan IMC = 0; sedangkan, pasar tersegmentasi apabila b1 $=b 3$ dan IMC = tak terhingga. Dalam kondisi normal indeks adalah positif dan nilai b1 antara 0 hingga -1 . IMC mendekati 0 , menunjukkan integrasi kedua pasar yang tinggi. Hytens \& Timer (1986) dalam Asmarantaka (2012) menyatakan, bila nilai IMC < 1 mencerminkan integrasi yang tinggi dalam jangka pendek (ada kemungkinan untuk b2 menuju 1 dan IMC menjadi sangat tinggi).

Integrasi dapat bersifat kuat dan lemah (Tabel 1). Integrasi kuat artinya jika perubahan harga di tingkat eksportir secara nyata dapat dirasakan 
perubahannya oleh petani. Sedangkan integrasi bersifat lemah yaitu perubahan harga di tingkat petani akan mempengaruhi harga di tingkat eksportir tidak terlalu signifikan.

Tabel 1. Syarat Suatu Pasar Terintegrasi atau Tidak

\begin{tabular}{llll}
\hline No & Keterangan & Jangka Pendek & Jangka Panjang \\
\hline 1 & Integrasi Kuat & $\begin{array}{l}\text { IMC mendekati } 0 \\
\text { IMC }<1\end{array}$ & $\mathrm{~b}_{2}$ mendekati $1(>0,5)$ \\
2 & Integrasi Lemah & IMC $>1$ & $\mathrm{~b}_{2}$ mendekati $0(<0,5)$ \\
3 & $\begin{array}{l}\text { Tidak Ada Hubungan/ } \\
\text { Tidak Terintegrasi }\end{array}$ & IMC tinggi & $\mathrm{b}_{2}$ sangat mendekati 0 \\
\hline
\end{tabular}

Sumber: Rosiana (2012)

\section{HASIL DAN PEMBAHASAN}

\section{Identifikasi Struktur Pasar}

Dalam analisis identifikasi pasar dilakukan deskripsi mengenai faktor jumlah pembeli dan penjual, sifat produk (dari sudut pandang pembeli), hambatan masuk dan keluar pasar serta informasi mengenai harga gambir di Kabupaten Lima Puluh Kota. Hal ini senada dengan Wardiyati dalam Rosiana (2012) yang menyatakan identifikasi struktur pasar dapat dilihat melalui faktor jumlah pedagang, barrier entry, ada tidaknya kolusi dan konsentrasi pasar.

Faktor jumlah pembeli dan penjual berkaitan dengan perbandingan jumlah partisipan di dalam pasar. Dalam penelitian ini, partisipan yang dibandingkan terdiri atas 4 level, yaitu petani, pedagang pengumpul, pedagang besar dan eksportir. Tabel 2 menggambarkan perbandingan jumlah partisipan pasar gambir di Kabupaten Lima Puluh Kota, Sumatera Barat. 
Tabel 2. Perbandingan jumlah partisipan pasar gambir di Kabupaten Lima Puluh Kota Serta Volume Gambir Tahun 2014

\begin{tabular}{lrrrr}
\hline Kecamatan & \multicolumn{1}{c}{$\begin{array}{c}\text { Populasi } \\
\text { Petani }{ }^{1}\end{array}$} & $\begin{array}{l}\text { Perkiraan } \\
\text { Jumlah } \\
\text { Pedagang } \\
\text { Pengumpul }\end{array}$ & $\begin{array}{c}\text { Perkiraan } \\
\text { Jumlah } \\
\text { Pedagang } \\
\text { Besar }\end{array}$ & $\begin{array}{c}\text { Perkiraan } \\
\text { Jumlah } \\
\text { Pedagang } \\
\text { Eksportir }^{2}\end{array}$ \\
\hline Kapur IX & 3.497 & 20 & 7 & \\
Mungka & 467 & 10 & 4 & 5 \\
Harau & 715 & 2 & 5 & \\
Lainnya & 3.323 & 18 & $7.272^{5)}$ & $2.747^{4)}$ \\
Volume /Ton/ & $7.934,17^{3)}$ & $3.825^{5)}$ & 7.20 &
\end{tabular}

Sumber 1) BAPPEDA (2013), 2)Dinas Perindustrian dan Perdagangan Provinsi Sumatera Barat (2014), 3) Dinas Tanaman Pangan Holtikultura dan Perkebunan Kabupaten Lima Puluh Kota (2014), ${ }^{4)}$ BPS (2013a), ${ }^{5)}$ diolah

Dari Tabel 2 terlihat Jumlah petani penghasil gambir yang ketidakseimbangan antara jumlah petani gambir dengan jumlah pedagang. Jumlah petani sebagai penjual relatif sangat banyak dan tidak sebanding dengan jumlah pedagang sebagai pembeli yang relatif sedikit. Kohls \& Uhl (2002) menyebutkan struktur pasar yang terdiri dari beberapa pembeli dari suatu produk atau komoditas dapat disebut sebagai pasar yang memiliki struktur oligopsoni. Gambaran ini memperlihatkan bahwa struktur pasar gambir termasuk dalam kategori pasar oligopsoni pada tingkat petani dan pedagang. Ketidakseimbangan ini menyebabkan peranan lembaga pemasaran (pedagang perantara) lebih kuat dan dominan dalam menentukan harga gambir dan cenderung menempatkan petani sebagai penerima harga (price taker).

Berdasarkan sifat produknya, produk yang diperdagangkan relatif homogen dengan bentuk gambir setengah jadi. relatif banyak akan menguntungkan pedagang untuk membeli gambir pada petani yang diinginkan. Sedangkan dari sisi penjual (petani), sifat produk yang homogen ini mengakibatkan semakin kecilnya peluang petani untuk menerima harga terbaik yang lebih menguntungkan bagi mereka.

Hambatan masuk dan keluar pasar akan dibahas berdasarkan masingmasing lembaga pemasaran yang terlibat dalam pemasaran gambir. Hambatan yang ditemui petani untuk keluar masuk pasar relatif rendah, mengingat jumlah petani yang sangat banyak. Keadaan yang demikian ini memposisikan petani sebagai penerima harga. Namun bila dihubungkan dengan pengembangan gambir, petani gambir cenderung menghadapi hambatan dalam permodalan. Hambataninimengakibatkan ketergantungan petani terhadap pedagang dalam hal permodalan dan 
menyebabkan semakin lemahnya posisi tawar petani gambir. Sedangkan pada tingkat pedagang, hambatan cenderung terjadi untuk pedagang pengumpul baru karena kuatnya ikatan kerjasama antar pedagang pengumpul lama ataupun dengan eksportir atau importir.

Pedagang besar yang telah lama bergerak dalam pemasaran gambir sebagian besar telah memiliki kerjasama yang kuat dengan eksportir lokal, eksportir luar serta pedagang besar di Pulau Jawa. Kerjasama yang dijalankan telah berlangsung selama bertahuntahun, sehingga pedagang besar cenderung memiliki akses yang kuat dalam pasar gambir. Kondisi keuangan pedagang besar yang relatif stabil juga turut berkontribusi terhadap posisinya dalam mempertahankan pasar gambir, sehingga bagi pedagang yang relatif baru akan cenderung menemui hambatan untuk keluar masuk pasar gambir.

Untuk eksportir, hambatan keluar masuk pasar gambir sangat terasa akibat peran importir India yang telah masuk ke pasar gambir di Sumatera Barat. Hambatan ini semakin diperbesar oleh pengetahuan importir gambir terhadap kultur petani Sumatera Barat, sehingga pergerakan eksportir menjadi cenderung lebih sulit dengan banyaknya kaki tangan importir yang telah memasuki daerahdaerah penghasil gambir khususnya di Kabupaten Lima Puluh Kota.

Disisi lain, informasi harga yang diperoleh hingga ke petani sangat berhubungan dengan informasi harga yang diperoleh pedagang dari eksportir. Eksportir memiliki kekuatan yang besar dalam menetapkan harga untuk ditingkat lembaga pemasaran dibawahnya, sehingga hal ini memperlihatkan adanya market power yang dimiliki eksportir. Kohls \& Uhl (2002) menyebutkan bahwa salah satu sumber market power dalam pemasaran berupa unequal information (informasi yang tidak seimbang), sehingga pada perdagangan gambir eksportir memiliki power untuk mengendalikan harga gambir.

Identifikasi struktur pasar menunjukkan bahwa pasar gambir cenderung mengarah ke oligopsoni, sehingga petani cenderung pada posisi price taker. Afrizal (2009); Rosiana (2012); Putri (2013) dan Alham (2013) menyebutkan bahwa struktur pasar yang cenderung mengarah pada pasar oligopsoni akan menyebabkan posisi petani sebagai price taker akibat dominasi pedagang yang mampu mengontrol petani baik itu dari segi harga maupun permodalan. Jumlah petani yang jauh lebih banyak banyak dibandingkan pembeli juga membuat pedagang memiliki market power dan memperlemah bargaining power petani.

\section{Saluran Pemasaran Gambir di Kabupaten Lima Puluh Kota}

Dari hasil penelitian diketahui ada 4 lembaga pemasaran yang terlibat dalam pemasaran gambir yaitu pengolah 
gambir, pedagang pengumpul, pedagang besar dan eksportir. Masing-masing lembaga pemasaran memiliki fungsi yang berbeda-beda dalam memberikan nilai (value). Selain itu, terdapat 4 saluran pemasaran yang terbentuk dalam pemasaran gambir di Kabupaten Lima Puluh Kota (Gambar 1), yaitu:

Saluran 1 : Petani-pedagang pengumpul-pedagang besar-eksportir lokal

Saluran 2 : Petani-pedagang besareksportir lokal

Saluran 3 : Pengolah-eksportir lokal/ pedagang besar di Pulau Jawa
Saluran 4 : Petani-pedagang pengumpul-pedagang besar di Pulau Jawa

Keempat saluran ini terbentuk berdasarkan hasil penelusuran pada tingkat petani hingga ke eksportir. Banyaknya saluran yang terbentuk sangat bergantung pada tingkat kebutuhan dan kemudahan petani dalam mengakses lembaga pemasaran yang dapat menyalurkan gambir hingga ke konsumen (dalam hal ini eksportir). Disisi lain, terbentuknya saluran ini juga berkaitan dengan harga yang ditawarkan oleh masing-masing lembaga pemasaran.

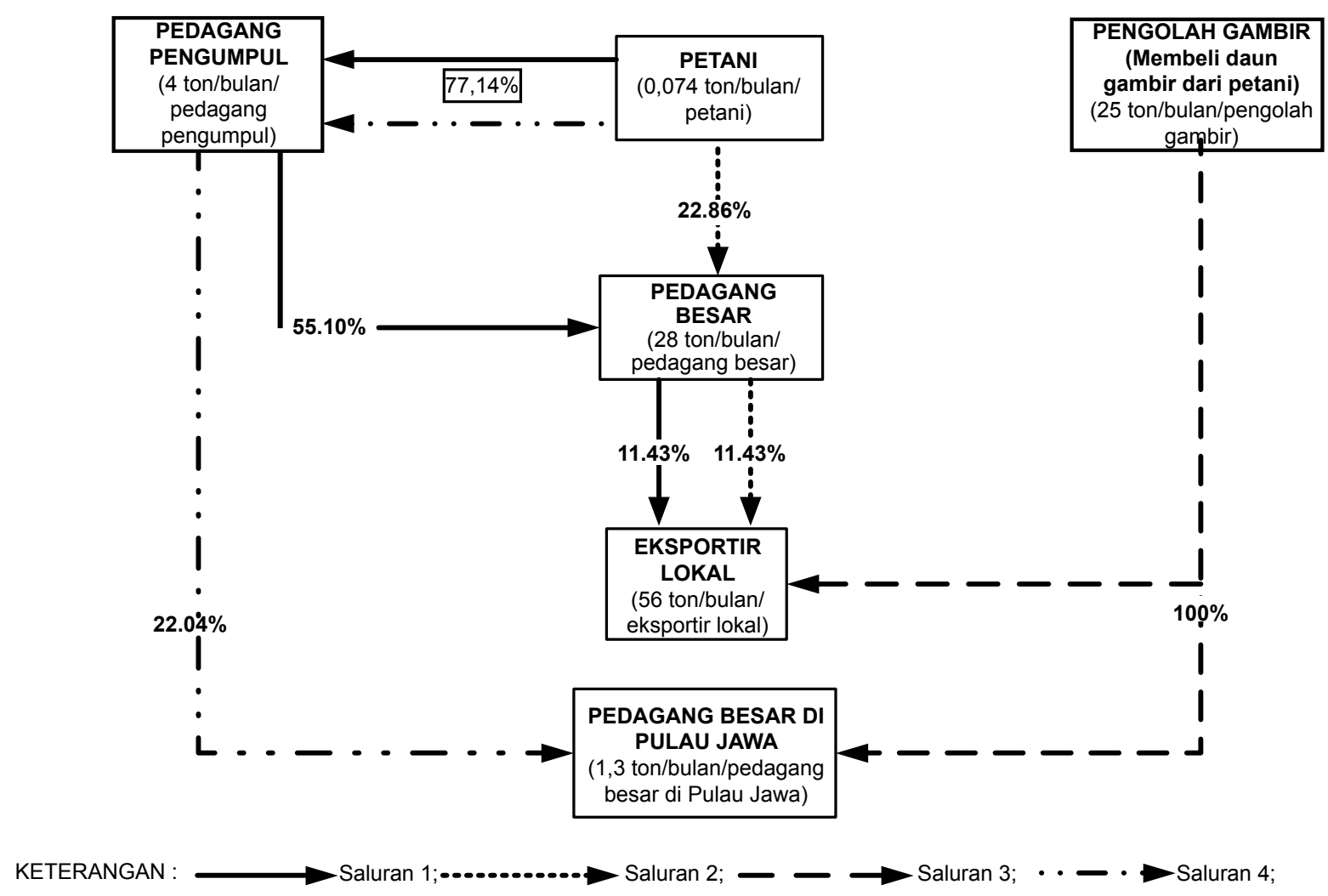

Gambar 1. Saluran pemasaran di Kabupaten Lima Puluh Kota

Sumber: Data Primer (2015), diolah 


\section{Mekanisme Pembentukan Harga}

Dalam penetapan harga gambir, eksportir memiliki kontribusi yang kuat sebagai penentu. Dilain pihak, eksportir juga memiliki ketergantungan dari segi harga berdasarkan nilai tukar rupiah terhadap dollar, keadaan ekonomi dan regulasi pemerintah di negara tujuan ekspor serta kuantitas yang dibutuhkan ketika penandatangan kontrak dilakukan dengan buyers. Secara teknis penentuan harga gambir tentunya berdasarkan kualitas gambir yang dihasilkan. Dari hasil penelitian ini dapat disimpulkan bahwa eksportir merupakan lembaga yang paling dominan dalam penentuan harga.

\section{Sistem Pembayaran}

Sistem pembayaran yang berlaku dalam pemasaran gambir memiliki beberapacara, diantaranya:pembayaran dimuka (33.33\%), pembayaran tunai $(61.90 \%)$ dan pembayaran setengah dari hasil penjualan gambir (4.76\%). Pembayaran dimuka ini berkaitan dengan modal tenaga kerja dalam kegiatan pengolahan gambir. Kegiatan pengempaan merupakan bagian yang paling banyak menghabiskan biaya hingga gambir siap dijual. Petani yang mengambil pinjaman diawal atau meminta pembayaran sebelum gambir siap dikempa biasanya mendapatkan harga gambir yang lebih rendah dari pedagang. Hal ini bukan saja karena potongan hutang yang harus dibayarkan, melainkan juga berkaitan dengan harga jual yang biasanya lebih murah dibandingkan petani yang tidak memiliki pinjaman dengan selisih antara $0.9 \%$ hingga $1.02 \%$.
Pembayaran tunai diterima oleh petani yang tidak memiliki pinjaman dengan pedagang. Petani biasanya memilih untuk dibayar tunai karena terdesak kebutuhan ekonomi. Selain itu, petani yang tidak memiliki pinjaman dengan pedagang biasanya memiliki keleluasan untuk menjual gambir kepada pedagang yang memberikan harga bersaing. Sedangkan untuk petani yang tinggal menerima setengah dari harga penjualan, biasanya mereka memilih untuk melakukan penarikan sisa hasil penjualannya secara berkala selama 1 minggu. Tingkat kebutuhan ekonomi membuat petani tetap menjual hasil panennya, meskipun harga jual yang berlaku sedang rendah, ketika panen gambir misalnya. Tekanan kebutuhan untuk keluarga dan upah untuk anak kampo (tenaga kerja pengolah gambir) merupakan faktor utamanya.

\section{Analisis Efisiensi Pemasaran Gambir}

Persoalan tidak efisiennya sistem pemasaran gambir merupakan salah satu hal yang menjadi sorotan dalam pengembangan gambir sebagai salah satu komoditas ekspor Indonesia. Sistem agribisnis yang terdiri dari subsitem agribisnis hulu, subsistem agribisnis usahatani, subsistem agribisnis pengolahan, subsistem agribisnis pemasaran dan subsistem agribisnis jasa dan penunjang secara normatif seharusnya memiliki keterkaitan satu sama lain bila dihubungkan dengan pengembangan agribisnis.

Ukuran efisiensi adalah kepuasan dari konsumen, produsen maupun lembaga-lembaga yang terlibat dalam 
mengalirkan barang atau jasa mulai dari petani sampai konsumen akhir. Dengan demikian, efisiensi pemasaran dapat dilihat dari dua indikator yaitu efisiensi operasional dan efisiensi harga (Kohls \& Uhl 2002). Ketidakefisienan dalam pemasaran gambir dapat dilihat dari penetapan harga yang dipegang oleh eksportir, struktur pasar yang oligopsoni yang dicirikan dengan tidak seimbangnya rasio petani dan pedagang, seperti yang telihat pada tingginya derajat konsentrasi pasar, serta informasi harga yang tidak ditransmisi secara sempurna bahkan cenderung tertutup (Afrizal, 2009; Elida, 2011). Kondisi tersebut mengakibatkan tidak akan ada harga terbaik atau harga yang menguntungkan yang akan berlaku bagi petani, dan yang lebih lanjut berdampak pada rendahnya tingkat kesejahteraan petani.

\section{Efisiensi Operasional dalam Pemasaran Gambir}

Berdasarkan saluran pemasaran gambir, diketahui terdapat 4 saluran yang dilalui dalam pemasaran gambir. Namun pada analisis ini, saluran 4 tidak termasuk dalam pembahasan karena batasan lokasi penelitian. Pada saluran
4 ini pedagang pengumpul melakukan penjualan kepada pedagang besar di Pulau Jawa, yang artinya berada diluar batasan penelitian berdasarkan lokasi penelitian.

Perhitungan analisis margin pemasaran pada masing-masing saluran pemasaran dilakukan dengan mempertimbangkan harga beli, harga jual dan biaya pemasaran pada masingmasing tingkat lembaga pemasaran. Biaya pemasaran yang dikeluarkan masing-masing lembaga pemasaran berkaitan dengan biaya susut (kadar air dan kemasan), bongkar muat, transportasi, pengeringan, kemasaran, penyimpanan, dan ekspor. Total margin diperoleh dari penjumlahan semua margin pada tingkat lembaga pemasaran. Disisi lain, juga dilakukan perhitungan analisis farmer's share. Berbeda halnya dengan margin pemasaran, farmer's share merupakan bagian yang diterima oleh petani. Oleh karena itu, farmer's share ini hanya mempertimbangkan pembagian antara harga jual ditingkat petani dengan harga jual ditingkat eksportir dalam bentuk persentase.

Tabel 3 Sebaran total biaya pemasaran, total keuntungan, total margin dan total farmer's share pada masing-masing saluran di Kabupaten Lima Puluh Kota

\begin{tabular}{ccccrrrr}
\hline Saluran & $\begin{array}{c}\text { Harga } \\
\text { beli } \\
\text { (petani) }\end{array}$ & $\begin{array}{c}\text { Harga jual } \\
\text { (eksportir) }\end{array}$ & $\begin{array}{c}\text { Total Biaya } \\
\text { Pemasaran }\end{array}$ & $\begin{array}{c}\text { Total } \\
\text { Keuntungan }\end{array}$ & $\begin{array}{c}\text { Total } \\
\text { Margin }\end{array}$ & $\begin{array}{c}\text { Farmer's } \\
\text { Share }\end{array}$ & $\begin{array}{c}\text { Rata } \\
\text { Volume/ } \\
\text { Tahun (ton) }\end{array}$ \\
\hline 1 & 21326.9 & 32546.8 & 3885.7 & 11271.9 & 11552.1 & 69.06 & 0.84 \\
2 & 22666.7 & 32546.8 & 3695.7 & 9206.7 & 9880.2 & 72.86 & 1.08 \\
3 & 23500 & 32546.8 & 2245.2 & 4566.4 & 6788.9 & 77.59 & 12 \\
\hline
\end{tabular}

Sumber: Data Primer (2015), diolah 
Berdasarkan hasil perhitungan pada Tabel 3, saluran yang relatif efisien ditunjukkan oleh saluran 3 (pengolah dan eksportir) yang memiliki total margin terkecil $(R p 6.788,90)$ dan share harga yang paling tinggi (77.59\%) dibandingkan 2 saluran lainnya. Pada saluran 3, harga ditingkat pengolah lebih tinggi dibandingkan harga pada tingkat petani di dua saluran lainnya. Selain itu, saluran 3 juga menunjukkan total biaya pemasaran yang lebih kecil dibandingkan saluran lainnya yaitu $7.41 \%$ dari harga jual dan persentase total keuntungan yang lebih kecil dibandingkan saluran 1 dan 2 yaitu $15.07 \%$, sehingga rasio keuntungan terhadap biaya pada saluran 3 , relatif lebih kecil dibandingkan saluran 1 .

Akan tetapi untuk menyimpulkan saluran mana yang relatif efisien, maka diperlukan pertimbangan lainnya berupa jumlah transaksi pembelian gambir dari tingkat petani. Hasil penelitian menunjukkan bahwa pada saluran 3 , pengolah gambir mampu memproduksi gambir sebanyak 12 ton/bulan atau 1-1.5 ton/hari dan hal ini tidak reliable untuk dilakukan petani secara perorangan akibat kecilnya kemungkinan petani mampu membuat pabrik gambir dengan kapasitas produksi 1-1,5 ton per hari dan terbatasnya akses yang mereka miliki dengan eksportir. Petani gambir yang sangat sulit dalam mengakses modal mengakibatkan mereka sulit melakukan ekspansi pengolahan gambir skala industri. Dengan demikian, apabila ingin memperoleh tingkat efisiensi yang sama untuk saluran 3 , maka diperlukan kerjasama antar petani untuk pembentukan kelompok dan mendirikan pabrik pengolahan skala industri.

Jika dilakukan perbandingan antara volume transaksi pembelian pada saluran 1 dan 2 terlihat bahwa saluran 1 yang terdiri dari petani, pedagang pengumpul, pedagang besar dan eksportir bersedia menampung hasil produksi petani yang lebih sedikit dibandingkan saluran 2. Meskipun dengan total margin yang lebih tinggi dan biaya pemasaran yang lebih besar serta persentase biaya pemasaran dan keuntungan terhadap harga jual (12.94\% dan $31.42 \%)$, saluran 1 menunjukkan relatif tidak efisien, namun menjadi alternatif terbesar petani dalam melakukan penjualan gambir. Hal ini disebabkan oleh kesediaan pedagang pengumpul untuk menerima hasil produksi gambir petani yang hanya 0.51 ton/ha. Kondisitersebut berdampak pada ketergantungan petani pada pedagang pengumpul, sehingga petani cenderung menerima berapapun harga yang ditetapkan pedagang pengumpul. Hal ini dapat dilihat dari harga jual ditingkat petani pada saluran 1 , sebagai harga terendah dibandingkan 2 saluran lainnya yaitu Rp 21328.13 (Saluran $2=\operatorname{Rp} 22666.7$ dan Saluran $3=\operatorname{Rp} 23$ 500.00).

Disisi lain, setiap lembaga yang melakukan pemasaran gambir pada masing-masing saluran memiliki biaya pemasaran yang berbeda-beda. Biaya pemasaran yang harus dikeluarkan petani berkaitan dengan biaya susut gambir yang biasa disebut pemotongan kadar air. Sedangkan untuk pedagang, biaya pemasaran yang harus dikeluarkan 
adalah biaya bongkar muat, transportasi, pengeringan, kemasan, biaya susut dan biaya untuk penyimpanan.

Berdasarkan analisis margin dapat diketahui bahwa faktor-faktor yang mempengaruhi margin pemasaran gambir di Kabupaten Lima Puluh Kota adalah harga gambir ditingkat petani, ditingkat pedagang pengumpul, ditingkat pedagang besar serta harga gambir ditingkat eksportir. Hal ini senada dengan penelitian Emokaro \& Egbodion (2014) yang menyatakan bahwa faktor utama yang mempengaruhi margin pemasaran adalah tingginya fluktuasi harga produk, penjualan serta sifat produk. Analisis pada Kabupaten Lima Puluh kota menunjukkan fungsi margin masing-masing tingkatan lembaga selain dipengaruhi oleh harga, juga dipengaruhi oleh biaya. Menurut Abbasian et al. (2010) pemasaran dipengaruhi oleh harga pedagang, biaya pemasaran dan harga petani dan dari 3 faktor tersebut, harga petani menjadi faktor yang lebih berpengaruh terhadap total marketing margin. Hal ini juga dapat dilihat pada margin pemasaran gambir yang menunjukkan bahwa harga pada tingkat petani sangat mempengaruhi besaran margin yang diperoleh pada pemasaran gambir.

Untuk mempertimbangkan efisiensi pemasaran gambir secara menyeluruh, diperlukan juga pertimbangan lainnya untuk memutuskan apakah suatu pemasaran efisien atau tidak. Kecenderungan kesimpulan pada analisis efisiensi operasional yang menunjukkan saluran 2 relatif efisien belum bisa menjadi patokan bahwa saluran pemasaran gambir di Kabupaten Lima Puluh Kota dapat dikatakan efisien. Hal ini disebabkan oleh posisi petani dalam pemasaran gambir yang menjadi price taker. Oleh karena itu, diperlukan pertimbangan struktur pasar gambir yang terbentuk dan analisis efisiensi harga.

\section{Efisiensi Harga dalam Pemasaran Gambir}

Analisis efisiensi yang dilakukan dalam penelitian ini berkaitan dengan analisis integrasi pasar vertikal yang dilakukan untuk 3 lembaga pemasaran yaitu petani, pedagang besar dan eksportir. Analisis pertama dilakukan pada tingkat petani sebagai pasar lokal dan pada tingkat pedagang besar dan eksportir sebagai pasar acuan. Analisis yang kedua dilakukan pada tingkat pedagang besar sebagai pasar lokal dan pada tingkat eksportir sebagai pasar acuan.

\section{Integrasi Jangka Pendek}

Berdasarkan hasil perhitungan analisis integrasi pasar jangka pendek dengan menggunakan Index of Market Connection (IMC) ditemukan bahwa nilai IMC untuk kedua analisis integrasi pasar pada pemasaran gambir lebih besar dari satu (Tabel 4). Nilai IMC menunjukkan bahwa persentase relatif harga produsen di pasar lokal saat ini tidak dipengaruhi oleh perubahan di pasar acuan di waktu sebelumnya. Ini berarti tidak terjadi integrasi pada pemasaran gambir dalam jangka pendek. 
Tabel 4. Indeks integrasi jangka pendek pada pasar gambir

\begin{tabular}{clcc}
\hline \multicolumn{1}{c}{ Pasar Lokal } & Pasar Acuan & IMC & Keterangan \\
\hline Petani & Pedagang Besar & 10,78 & Tidak terintegrasi jangka pendek \\
& Eksportir & 3,01 & Tidak terintegrasi jangka pendek \\
Pedagang Besar & Eksportir & 15,64 & Tidak terintegrasi jangka pendek \\
\hline
\end{tabular}

Sumber: Data Primer (2015), diolah

Analisis pertama berkaitan dengan petani sebagai pasar lokal dan pedagang besar serta eksportir sebagai pasar acuan. Dari Tabel 4 dapat dilihat bahwa tidak adanya integrasi harga dalam jangka pendek antara tingkat petani dengan pedagang besar dan eksportir. Hal ini menunjukkan bahwa perubahan harga gambir pada tingkat pedagang besar dan eksportir pada waktu sebelumnya tidak mempengaruhi harga gambir tingkat petani saat ini.

Analisis kedua melihat integrasi antara pedagang besar dan eksportir. Berdasarkan hasil penelitian diketahui bahwa pedagang besar tidak memiliki integrasi dengan eksportir dalam jangka pendek. Ini berarti perubahan harga gambir pada tingkat eksportir pada waktu sebelumnya tidak mempengaruhi harga gambir pada tingkat pedagang besar saat ini.

Tidak terintegrasinya harga pada pasar acuan dengan pasar lokal menunjukkan bahwa perubahan harga gambir pada pasar acuan pada waktu sebelumnya tidak mempengaruhi harga saat ini pada pasar lokal. Hal ini bisa terjadi karena informasi harga pada pasar acuan tidak tersalurkan pada pasar lokal. Selain itu, hasil analisis ini juga menunjukkan bahwa perubahan harga yang terjadi di pasar lokal cenderung dipengaruhi oleh harga sebelumnya pada pasar lokal tersebut.

\section{Integrasi Jangka Panjang}

Integrasi pasar jangka panjang berkaitan dengan hubungan antara perubahan harga dipasar acuan yang ditransmisikan kepada pasar lokal dalam jangka panjang. Hal ini dapat dilihat dari nilai koefisien $b_{2}$. Nilai yang dihasilkan adalah satu atau mendekati satu. Apabila nilai koofisien $b_{2}$ adalah $1\left(b_{2}=1\right)$, maka kedua pasar tersebut terintegrasi dalam jangka panjang. Pada analisis ini, integrasi jangka panjang yang dianalisis berkaitan dengan analisis antara petani gambir dengan pedagang besar dan eksportir serta antara pedagang besar dengan eksportir.

Tabel 5. Indeks integrasi jangka panjang pada pasar gambir

\begin{tabular}{clc}
\hline Pasar Lokal & \multicolumn{1}{c}{ Pasar Acuan } & Long Run $\left(\mathrm{b}_{2}\right)$ \\
\hline Petani & Pedagang Besar & 0,02 \\
& Eksportir & 0,05 \\
Pedagang Besar & Eksportir & 0,22 \\
\hline
\end{tabular}

Sumber: Data Primer (2015), diolah 
Analisis pertama melihat hubungan antara pasar lokal (petani) dengan pasar acuan (pedagang besar dan eksportir). Dari nilai $b_{2}$ pada Tabel 5 menyatakan bahwa dalam jangka panjang petani tidak memiliki integrasi pasar dengan pedagang besar dan eksportir. Hal ini ditunjukkan oleh nilai koofisien $b_{2}$ yang tidak sama dengan $1\left(b_{2} \neq 1\right)$, bahkan lebih kecil dari taraf nyata 0.05 . Yang artinya, perubahan harga yang terjadi ditingkat eksportir dan pedagang besar tidak ditransmisikan kepada petani gambir.

Analisis kedua berkaitan dengan hubungan antara pedagang besar dan eksportir. Berdasarkan nilai koofisien $\mathrm{b}_{2}$ dapat diketahui tidak terdapat hubungan integrasi jangka panjang antara pasar acuan (eksportir) dengan pasar lokal (pedagang besar) karena nilai koofisiennya $b_{2}$ yang tidak sama dengan $1\left(b_{2} \neq 1\right)$. Namun dengan nilai koofisien yang lebih besar dari taraf nyata (0.05) yaitu 0.22 , maka dapat disimpulkan bahwa perubahan harga yang terjadi pada tingkat eksportir berkorelasi dengan perubahan harga pada tingkat pedagang besar, namun tidak ditransmisikan kepada pedagang besar dalam jangka panjang.

Hasil analisis ini menunjukkan bahwa dalam jangka panjang harga gambir ditingkat petani (pasar lokal) saat ini tidak dipengaruhi oleh harga gambir di tingkat pedagang besar dan eksportir (pasar acuan) pada waktu sebelumnya. Hal ini menyebabkan perubahan harga yang terjadi pada pasar acuan (pedagang besar dan ekportir) tidak ditransmisikan ke pasar lokal (petani), sehingga petani tidak menerima perubahan atas harga yang terjadi di pasar acuan. Disisi lain, harga gambir di tingkat pedagang besar memiliki hubungan dengan harga gambir ditingkat eksportir. Hal ini berdampak pada kecenderungan adanya kolusi antara pedagang besar dan eksportir. Akibatnya petani tidak memiliki akses untuk mengetahui harga yang sebenarnya akibat permainan diantara pedagang besar dan eksportir. Hubungan tersebut mengindikasikan bahwa harga yang ditetapkan pedagang besar merupakan harga yang hanya mempertimbangkan fee yang akan diterima pedagang besar dari eksportir. Dengan demikian, pedagang besar cenderung menjadi kaki tangan eksportir dalam sistem pemasaran gambir.

\section{Implikasi Efisiensi Pemasaran Terhadap Pembentukan Harga Gambir}

Berdasarkan analisis identifikasi struktur pasar ditemukan bahwa pasar gambir mengarah kepada oligopsoni dari sisi pembeli, dengan adanya hambatan untuk keluar masuk pasar gambir. Tidak adanya informasi permintaan dan tidak berlakunya sistem kuota dalam pemasaran gambir menyebabkan petani hanya bertindak sebagai price taker.

Perhitungan analisis integrasi pasar vertikal menunjukkan bahwa pasar acuan tidak terintegrasi dengan pasar lokal yang disebabkan oleh tidak tertransmisikannya informasi harga gambir dari pasar acuan ke pasar lokal, sehingga dengan demikian perubahan harga gambir pada pasar acuan tidak mempengaruhi pasar lokal. Hal ini ditunjukkan oleh nilai IMC yang lebih dari 1 dan nilai $b^{2}$ yang tidak mendekati 
1. Dalam jangka panjang harga gambir ditingkat pedagang besar, memiliki korelasi dengan harga gambir ditingkat eksportir namun informasi harga tidak tertransmisi, sehingga kecenderungan adanya kolusi pada jangka panjang semakin besar, dan hal ini diperkuat dengan struktur pasar yang oligopsoni.

Posisi pedagang pengumpul dan pedagang besar sebagai kaki tangan lembaga diatasnya menunjukkan adanya market power dalam pemasaran gambir, yang terbentuk melalui pembuatan jaringan pemasaran yang kuat. Pada akhirnya, kondisi ini menyebabkan petani tidak memiliki akses dan kesempatan untuk menjual gambir kepada pihak-pihak yang dianggap lebih menguntungkan. Adanya indikasi berupa kolusi antara lembaga pemasaran gambir dalam jangka panjang menunjukkan bahwa posisi pedagang pungumpul dan pedagang besar sebagai kaki tangan lembaga pemasaran diatasnya (eksportir), sehingga hal ini dapat memperlihatkan market power yang dimiliki lembaga pemasaran. Kohls \& Uhl (2002) menyebutkan market power merupakan kemampuan untuk mempengaruhi pasar, perilaku pasar ataupun hasil pasar. Market power ini bersumber dari: 1) ukuran dan besar konsentrasi pasar dari sebuah perusahaan; 2) kontrol permintaan; 3) informasi yang tidak seimbang; 4) diversifikasi; 5) pembedaan produk; 6) kontrol dari sumberdaya stategik dan keputusan; 7) sumberdaya keuangan; dan 8) rasio biaya tetap dan biaya variabel. Dari beberapa sumber tersebut, lembaga pemasaran gambir memiliki beberapa sumber bagi terbentuknya market power seperti kepemilikan informasi harga serta sumberdaya keuangan. Pada akhirnya dengan 2 sumber tersebut lembaga pemasaran gambir mampu memperlihatkan market powernya dalam perdagangan gambir di Kabupaten Lima Puluh Kota.

Disisi lain, hambatan lain yang ditemui dalam pemasaran gambir akibat market power lembaga pemasaran adalah melalui pembatasan pasar gambir yang hanya menerima gambir hasil kempaan petani dalam bentuk olahan setengah jadi dengan kualitas yang rendah. Sedangkan untuk olahan yang lebih baik berupa gambir murni, cenderung terhambat pemasarannya dengan kecilnya pasar yang menampung hasil pengolahan tersebut serta penetapan harga gambir yang tidak memiliki standar yang jelas antara gambir kualitas bagus dan jelek. Akibatnya petani lebih memilih mengolah gambir dengan kualitas campuran.

Kondisi ini mengakibatkan tingginya harapan terhadap pemerintah untuk memperbaiki sistem pemasaran gambir agar lebih efisien. Hal ini senada dengan Firdaus \& Gunawan (2012) yang menyebutkan dibutuhkannya intervensi dari pemerintah untuk meningkatkan efisiensi pemasaran. Salah satu tindakan yang dapat dilakukan adalah perbaikan dan penguatan kelembagaan tingkat petani untuk memperlemah market power pedagang perantara dan memperkuat bargaining power petani. Selain itu, sangat dibutuhkan peran intelegen pasar melalui perbaikan pusat informasi harga dan ekspor gambir 
serta melakukan kegiatan promosi untuk mendapatkan pasar baru bagi pemasaran gambir. Dengan demikian, peluang pemasaran gambir yang tertutupi oleh market power pedagang perantara dapat diatasi, sehingga diharapkan akan tercipta pemasaran yang lebih efisien dan adil.

\section{KESIMPULAN DAN REKOMENDASI KEBIJAKAN}

Berdasarkan indikator analisis efisiensi operasional dan efisiensi harga dapat disimpulkan bahwa sistem pemasaran gambir tidak efisien akibat posisi tawar petani yang rendah. Petani berperan hanya sebagai penerima harga. Akan tetapi, bila dilihat berdasarkan margin terendah dan farmer's share tertinggi dapat diketahui bahwa saluran yang relatif efisen dan reliabel untuk diaplikasikan pada tingkat petani adalah saluran 2 .

Struktur pasar gambir di Kabupaten Lima Puluh Kota cenderung mengarah pada struktur pasar oligopsoni, sehingga mengakibatkan lemahnya bargaining power petani. Adanya korelasi pasar gambir di tingkat pedagang besar dengan eksportir memungkinkan terjadinya kolusi antar lembaga pemasaran (pedagang perantara) gambir, sehingga pedagang pengumpul dan pedagang besar cenderung menjadi kaki tangan ekportir dan petani cenderung berada pada posisi penerima harga dalam pasar gambir. Disisi lain, adanya market power berupa pembatasan pasar gambir juga turut berkontribusi dalam menghambat perkembangan pemasaran gambir yang lebih adil dan berpihak pada petani gambir.
Oleh karena itu, peran pemerintah sangat diharapkan dalam meningkatkan akses petani terhadap informasi pasar gambir melalui perbaikan pusat informasi harga gambir serta melakukan kegiatan promosi untuk mendapatkan pasar baru bagi pemasaran gambir. Pemerintah dengan demikian akan mendapatkan peluang yang lebih luas untuk menciptakan pemasaran gambir yang lebih menguntungkan bagi petani gambir.

\section{UCAPAN TERIMAKASIH}

Direktorat Jenderal Penelitian Pendidikan Tinggi (Kementerian Riset dan Teknologi) melalui Beasiswa Pendidikan Pascasarjana Dalam Negeri (BPP-DN) Calon Dosen tahun 2013.

\section{DAFTAR PUSTAKA}

Abbasian, M., F.S. Bidabadi, H. Ebrahimzadeh. (2010). Efficiency of Date Marketing System in Sistan and Bluchestan of Iran; a Marketing Margin Approach. AGRIC. ECON-CZECH. Vol 56(1): 43-50.

Adi, A. H. B. (2011). Pengembangan Agroindustri Gambir di Kabupaten Lima Puluh Kota, Sumatera Barat [Disertasi]. Bogor: Institut Pertanian Bogor.

Afrizal, R. (2009). Analisis Produksi dan

Pemasaran Gambir di Kabupaten Lima

Puluh Kota, Provinsi Sumatera Barat [Tesis]. Bogor: Institut Pertanian Bogor Alham F. (2013). Analisis Pemasaran Garam Di Kabupaten Sumenep Jawa Timur. [Tesis]. Bogor: Institut Pertanian Bogor. Asmarantaka, R.W. (2012). Pemasaran Agribisnis (Agrimarketing). Bogor: Departemen Agribisnis. Fakultas Ekonomi Manajemen. Institut Pertanian Bogor 
Badan Pusat Statistik Sumatera Barat. (2013). Statistik Perdagangan Luar Negeri Sumatera Barat (Ekspor-Impor). Sumatera Barat: Badan Pusat Statistik Sumatera Barat.

Badan Pusat Statistik Sumatera Barat. (2014). Sumatera Barat Dalam Angka. Sumatera Barat : Badan Pusat Statistik Sumatera Barat.

BAPPEDA Badan Perencanaan dan Pembangunan Daerah Kabupaten Lima Puluh Kota. (2013). Pedoman Pengembangan (Master Plan) Gambir Kabupaten Lima Puluh Kota Tahun 2011-2015. Kabupaten Lima Puluh Kota : BAPPEDA

BAPPENAS; GIZ Badan Perencanaan dan Pembangunan Nasional, Deutsche Gesellschaft für Internationale Zusammenarbeit GmbH. (2013). Studi Kelayakan Usaha Pengolahan Produk Berbahan Baku Gambir di Kabupaten Lima Puluh Kota. Padang : BAPPENAS dan GIZ GmbH.

Dinas Perindustrian dan Perdagangan

Provinsi Sumatera Barat. (2014). Company Profile of Export Comodity From West Sumatera-Indonesia.

Dinas Tanaman Pangan Holtikultura dan

Perkebunan Kabupaten Lima Puluh Kota. (2014). Perkembangan Harga Pasar Komoditi Perkebunan.

Elida, S. (2011). Strategi Pemasaran Gambir Kabupaten Kampar. Jurnal Sosial Ekonomi Pembangunan. Vol 1 (3): 246-257.

Evalia, N.A., E.G. Sa'id., R.N. Suryana. (2012). Strategi Pengembangan Agroindustri dan Peningkatan Nilai Tambah Gambir di Kabupaten Lima Puluh Kota Sumatera Barat. Jurnal
Manajemen dan Agribisnis. Vol 9(3): 173-182.

Emokaro, C.O., J. Egbodion. (2014). Effect of Marketing Cost on Marketing Margin Realizanle from Beef Sales in Benin City Nigeria. Sciencedomain Internasional. American Journal of Experimental Agriculture, Vol 4(2): 215-224.

Firdaus M, \& Gunawan I. (2012). Integration Among Regional Vegetable Markets In Indonesia. J. ISSAAS. 18(2): 96-106.

Idrus, R.K. (2012). Trend Perkembangan Komoditi Unggulan Perkebunan Rakyat di Sumatera Barat. Jurnal Ekonomi STIE Haji Agus Salim Bukittinggi, Vol $\mathrm{XII}(2)$.

Kohls, R.I., J.N Uhl (2002). Marketing of Agricultural Products. Ninth Edition. New Jersey: Prentice Hall.

Putri MA. (2013). Sistem Pemasaran Kopi Arabika Gayo Di Kabupaten Aceh Tengah Dan Bener Meriah, Provinsi Aceh: Pendekatan Structure, Conduct, Performance (SCP) [Tesis]. Bogor: Institut Pertanian Bogor.

Rosiana, N. (2012). Sistem Pemasaran Gula Tebu (Cane Sugar) Dengan Pendekatan Structure, Conduct, Performance (SCP) [Kasus : Perusahaan Perseroan (Persero) PT. Perkebunan Nusantara VII Unit Usaha Bungamayang] [Tesis]. Bogor: Institut Pertanian Bogor

Sa'id, E.G. (2010). Review Kajian, Penelitian Dan Pengembangan Agroindustri Strategis Nasional: Kelapa Sawit, Kakao Dan Gambir. J. Tek. Ind. Pert.19(1): 45-55.

Trade Map. (2014). List Of Pathner for A Product Commercualized By Indonesia Product: 3201901000 Gambier 
